\title{
How the Criminal Law in Australia HAS FAILED TO PROMOTE THE RIGHT TO LIFE FOR UNBORN CHILDREN: A NEED FOR UNIFORM CRIMINAL LAWS ON ABORTION ACROSS AUSTRALIA
}

\section{PATRICK FERDINANDS*}

\begin{abstract}
This article contends that human life has an intrinsic value from the moment of its conception based on its potential use to the community. This value to the community demands protection from the state. However, there is also a need to balance this aim against the legitimate health interests of pregnant women. Abortions should be permitted only in circumstances where the abortion is necessary to preserve the pregnant woman from any serious danger to her physical or mental health. This article shows that the lack of uniformity in Australia's criminal law in the area of abortion plays a part in unduly undermining the right to life of unborn children. Accordingly, there is a need for effective uniform criminal laws throughout Australia that properly protect the right to life of unborn children and are duly sensitive to the valid health interests of pregnant women that give rise to circumstances justifying abortion.
\end{abstract}

\section{INTRODUCTION}

This article seeks to discover whether or not the criminal law in Australia has failed to promote the right to life for unborn children, and if so, how. It will also examine closely the lack of uniformity in Australia's criminal law in the area of abortion ${ }^{1}$ to see if it plays a part in undermining the rights of unborn

\footnotetext{
* BA (Deakin University), LLB (Hons) (Charles Darwin University), Grad.Dip.Leg.Prac (Australian National University), Public Servant, Victoria. The author thanks Dr David Price, Charles Darwin University, for his valuable comments on the draft of this article.

${ }^{1}$ See, eg, Abortion Law Reform Act 2008 (Vic) ss 1, 4, 5, which permits abortions to be carried out; Criminal Law Consolidation Act 1935 (SA) s 82A, which permits abortions to be carried out under prescribed circumstances; Criminal Code Act 1899 (Qld) ss 224-6, which makes it
} 
children. In particular, the article will examine whether there is a need for effective uniform criminal laws throughout Australia that properly protect the right to life for unborn children and are duly sensitive to the valid health interests of pregnant women that give rise to circumstances justifying abortion. $^{2}$

To examine this subject closely, this article will analyse a number of key questions. Firstly, it will look at the question of whether or not unborn children have rights, and in particular, the right to life. After all, if we wish to advocate effective criminal laws to safeguard unborn children, it must be known why they are worth protecting. Secondly, the article will look at exceptions that make it permissible for unborn children's rights to life to give way to the essential welfare of pregnant women. ${ }^{3}$ Thirdly, the article will critically examine specific areas of legislation in Australian 'pro-choice' jurisdictions and 'pro-life' jurisdictions. It will also look at how the criminal law on abortion has been applied in cases to determine whether or not the courts contribute to any failure of Australian law to promote the right to life of unborn children. Finally, the article will formulate a legal policy recommendation in support of the right to life for unborn children that could form the basis of future discussion with a view to law reform across Australia in the area of abortion crimes.

\section{The INTRINSic Value of Human Life - Why It Is WORTH PROTECTING THE LIFE OF AN UNBORN CHILD}

The polarising views of the pro-life and pro-choice camps on the abortion debate centre upon whether a human foetus is a child from the moment of conception or whether it is simply a collection of cells dependent on, and an extension of, a pregnant woman's body. ${ }^{4}$ This article does not seek to resolve this matter; neither camp has any irrefutable argument to offer the other to resolve this ideological conflict. ${ }^{5}$ What both sides may agree on, perhaps, is

a criminal offence to procure a miscarriage; Crimes Act 1900 (NSW) ss 82-4, which makes it a criminal offence to procure a miscarriage.

${ }^{2}$ See Roe v Wade, 410 US 113, 153, 162-5 (1973).

${ }^{3}$ See generally Rebecca Dean, 'Erosion of Access to Abortion in the United States: Lessons for Australia' (2007) 12(1) Deakin Law Review 123, 127-8.

${ }^{4}$ See Ronald Dworkin, Life's Dominion (Harper Collins Publishers, 1993) 10.

${ }^{5}$ Ibid 10,30 . 
that human life has an intrinsic value during any stage of its development ${ }^{6}$ a value that could justify the protection of a human foetus from conception. ${ }^{7}$

\section{A The Intrinsic Value of Human Life - Particularly Prenatal Life}

Ronald Dworkin offers an interesting notion of 'intrinsic value' in relation to human life, ${ }^{8}$ which is worth discussing briefly - although it is a somewhat problematic notion. ${ }^{9}$ Dworkin describes his notion of intrinsic value by contrasting it with the notion of 'instrumental value'. ${ }^{10}$ Something is instrumentally valuable if it has some use to others - that is, if it can be used by others to get what they want or need. ${ }^{11}$ Dworkin gives the examples of money and medicine: they are not more valuable than their respective abilities to purchase what people want or to cure people. ${ }^{12}$ In the context of human life, something is instrumentally valuable if it can be used by others to get what they want or need. ${ }^{13}$ That is to say, a person's life is useful because of the many things he or she is able to do for others that enrich their lives (in relationships, work, and so forth). ${ }^{14}$

Intrinsic value on the other hand is value that is independent of what people can make use of to get what they want or need. ${ }^{15}$ That is to say, something is intrinsically valuable irrespective of whether or not people want, need or enjoy it. ${ }^{16}$ This notion of intrinsic value is somewhat problematic because it is almost impossible to conceive of anything 'valuable' that has no possible use to others.

\footnotetext{
${ }^{6}$ Ibid $11,13$.

${ }^{7}$ Ibid 13 .

${ }^{8}$ Ibid 71-2.

${ }^{9}$ Nikolai Lazarev, 'The Intrinsic Value of Human Life: A Critique of Life's Dominion' (2005)

12(1) eLaw Journal: Murdoch University Electronic Journal of Law 7, II $<$ http://www.austlii.edu.au/au/journals/MurUEJL/2005/7.html>.

${ }^{10}$ Dworkin, above $\mathrm{n} 4,71-2$.

${ }^{11}$ Ibid 71.

${ }^{12}$ Ibid.

${ }^{13}$ Ibid.

${ }^{14}$ Ibid; Lazarev, above n 9, II.

${ }^{15}$ Dworkin, above n 4, 71; Lazarev, above n 9, II.

${ }^{16}$ Dworkin, above n 4, 71; Lazarev, above n 9, II.
} 
What is perhaps a better notion of intrinsic value is one that incorporates the idea of human life being valuable based on its usefulness to others. ${ }^{17}$ This notion is pragmatic and simple to apply in a legal context. ${ }^{18}$ With regard to an unborn child, society protects that life because of its assessment of the usefulness of that life to the community. ${ }^{19}$

The issue with the law is its artificial evaluation of the worth of an unborn child based on his or her 'present condition'; this is a patently flawed method of assessing the worth of human life. The law governing abortion attributes value to an unborn child based on which trimester he or she has progressed to. ${ }^{20}$ However, an unborn child's value to society based on his or her potential future use - which by its very nature is contingent - is a truer valuation of unborn children. ${ }^{21}$ This can be illustrated by the practical example of people investing in shares or property; such investment is not valued by the investor on the basis of the investment's present value, but on the basis of its potential future value - a potential that may or may not materialise. Yet the very significant potential value of unborn children, which crystallises at the moment of conception, ${ }^{22}$ is largely obscured by the law differentiating the value of unborn children during the phases of their development. ${ }^{23}$

This article suggests that the intrinsic value of an unborn child arises from the moment of conception and this intrinsic value is based on the potential use this life has to other human beings. The article also suggests that this notion of intrinsic value should form the basis of legal policy on the criminality of abortion, and that references in criminal statutes to discrete periods in the prenatal stage which attribute different value to the unborn child should be removed. In this way, from the moment of conception an unborn child could be treasured and offered real protection by the criminal law. This is a far cry from the current situation in Australia. A number of jurisdictions still differentiate the worth of unborn children based on their gestational ages, ${ }^{24}$

\footnotetext{
${ }^{17}$ Lazarev, above n 9, IV.

${ }^{18}$ See ibid IV.

${ }^{19}$ See ibid.

${ }^{20}$ Roe v Wade, 410 US 113, 163-5 (1973); Dean, above n 3, 127-8, 157-8; see also Criminal Code Act 1983 (NT) s 208B; Medical Services Act 1982 (NT) s 11.

${ }^{21}$ Roe $v$ Wade, 410 US 113, 150, 154, 156, 159, 162 (1973); see generally Dworkin, above n 4, 13.

${ }^{22}$ Dworkin, above n 4, 12-3; see generally Roe v Wade, 410 US 113, 159, 162 (1973).

${ }^{23}$ Roe v Wade, 410 US 113, 163-5 (1973); Dean, above n 3, 127-8, 157-8; see also Criminal Code Act 1983 (NT) s 208B; Medical Services Act 1982 (NT) s 11.

${ }^{24}$ For example, Criminal Code Act 1983 (NT) s 208B; Medical Services Act 1982 (NT) s 11; Criminal Law Consolidation Act 1935 (SA) s 82A.
} 
and this serves to undermine the protection the criminal law offers unborn children. This defect in the law can be remediated through a legal policy position that recognises the intrinsic value of unborn children from the moment of their conception.

The question now turns to what rights are properly ascribed to an unborn child in law.

\section{B Rights in Law of the Unborn}

What is interesting in a legal sense is that the law throughout the world is not uniform in ascribing rights to unborn children. The rights of unborn children vary between nations. ${ }^{25}$ To illustrate this point, it is worth very briefly contrasting Australia's position in this area with that of Ireland and also looking at what international law has to say on this subject.

Ireland has taken a very strong legal stance in the protection of unborn children, and this is perhaps due largely to its staunch Catholic culture. ${ }^{26}$ The Irish Constitution confers a right to life and offers legal protection for unborn children. Explicitly, the Constitution provides that the 'State acknowledges the right to life of the unborn and, with due regard to the equal right to life of the mother, guarantees in its laws to respect, and, as far as practicable, by its laws to defend and vindicate that right'. ${ }^{27}$ Whilst this constitutional provision ostensibly affords the opportunity for women to access abortion - for example, in instances where continuing pregnancy may jeopardise the life of the mother - the provision is about the unborn child's right to life and not the woman's right to choice. ${ }^{28}$ Domestic criminal law in Ireland gives effect to the constitutional protection of unborn childre ${ }^{29}$ and it is therefore clear that unborn children in Ireland enjoy a right to life. ${ }^{30}$

\footnotetext{
${ }^{25}$ Western Australia, Parliamentary Debates, Legislative Council, 18 March 1998, 736 (John Halden).

${ }^{26}$ Rachael Wright, 'The Silencing of Women: The Irish Abortion Laws and Religion' (2005) 6(3) Journal of International Women's Studies 64, 67.

${ }^{27}$ Constitution of Ireland (Ireland 1937) art 40.3.3.

${ }^{28}$ See Wright, above n 26, 65-6.

${ }^{29}$ See Offences Against the Person Act 1861 (UK) ss 58-9.

${ }^{30}$ See Constitution of Ireland (Ireland 1937) art 40.3.3.
} 
What the example of Ireland shows is that some nations recognise that unborn children have a right to life in their prenatal state. ${ }^{31}$ The stark difference between Ireland and Australia is that, under its common law, Australia holds that the rights of unborn children do not exist prior to their birth. ${ }^{32}$ That is to say, a child becomes a 'legal person' - with the ability and entitlement to enforce his or her legal rights - only upon being born alive. ${ }^{33}$ For example, in the case of Watt $v$ Rama ${ }^{34}$ a plaintiff sued for disability caused by the defendant's careless driving, which resulted in a collision with the car the plaintiff's mother was driving whilst the mother was pregnant with the plaintiff. ${ }^{35}$ The collision caused very serious injuries to the plaintiff's mother and disability to the plaintiff. ${ }^{36}$ The court established that the defendant had a duty of care to pregnant women and the children they were carrying via the 'reasonable foreseeability' test, that the defendant could breach this duty of care to an unborn child (via careless driving), and that damage (disability) to the child could arise after birth. However, it was only upon her birth that the plaintiff's injuries could be sustained by her as a 'legal person' and thus only then that she had a cause of action for negligence. ${ }^{37}$ That is, if an unborn child is injured, the child's cause of action 'crystallises' upon the injured child's birth, ${ }^{38}$ which is to say that the damage only exists when the child is born alive in a damaged condition. ${ }^{39}$ What is significant about this case is that the court recognised that a duty of care is afforded to unborn children and thus they are worth protecting, even though the court qualified this duty by imposing the requirement that the child must be born alive. ${ }^{40}$ The point nevertheless remains that in the case of abortion, the 'born alive rule' is of no use in supporting the right to life of unborn children. Australia, by comparison to Ireland, largely lacks the unequivocal legal protection given by the state to unborn children.

\footnotetext{
${ }^{31}$ Ibid. Note that a similar situation exists in the Philippines - see Constitution of the Republic of the Philippines 1987, art II, s 12, which provides that the 'State...shall equally protect the life of the mother and the life of the unborn from conception'.

${ }^{32}$ Pam Stewart and Anita Stuhmcke, 'Legal Pragmatism and the Pre-Birth Continuum: An Absence of Unifying Principle' (2007) 15 Journal of Law and Medicine 272, 272.

${ }^{33}$ Ibid; Watt v Rama [1972] VR 353; Paton v British Pregnancy Advisory Service Trustees [1979] QB 276, 279.

${ }^{34}$ [1972] VR 353.

${ }^{35}$ Watt $v$ Rama [1972] VR 353.

${ }^{36}$ Ibid.

${ }^{37}$ Ibid.

${ }^{38}$ Ibid; Stewart and Stuhmcke, above n 32, 280.

${ }^{39}$ Stewart and Stuhmcke, above n 32, 280.

${ }^{40}$ Watt v Rama [1972] VR 353; ibid.
} 
The significant differences in the rights of unborn children across different nations are perhaps symptomatic of the nature of the law. The classification of the foetus and its rights is the work of 'legal fiction'. ${ }^{41}$ Whilst the law might be informed by science, its pronouncements are not scientific. ${ }^{42}$ In many cases, the law departs from science and creates its own conceptions of what constitutes a 'legal person' in whom rights can be invested. ${ }^{43}$ The 'born alive' rule is no exception - in fact, its attractiveness to jurists is perhaps based on the simplicity of the rule rather than its scientific accuracy in classifying the development of unborn children. ${ }^{44}$

The position of international law with regard to the rights of unborn children could be inferred from the International Covenant on Civil and Political Rights (ICCPR) art 6(5), which Australia has ratified. ${ }^{45}$ The ICCPR provides that the '[s]entence of death shall not be ... carried out on pregnant women'. ${ }^{46}$ It is implicit in that statement that unborn children are protected and have a right to life, which cannot be violated by any state. ${ }^{47}$ The significance of this is that the ICCPR is a binding treaty for those nations that choose to ratify it ${ }^{48}$ 'and must be performed by them in good faith'. ${ }^{49}$

However, in Dietrich v The Queen the High Court of Australia observed that ratification of the ICCPR 'has no direct legal effect upon domestic law; the rights and obligations' under the ICCPR do not become Australian law 'unless and until specific legislation is passed implementing the provisions'. ${ }^{50}$ In other words, the right to life of unborn children does not exist under Australian law simply because the Australian executive government has

\footnotetext{
${ }^{41}$ Stewart and Stuhmcke, above n 32, 272.

${ }^{42}$ Tremblay $v$ Daigle [1989] 2 SCR 530, 553.

${ }^{43}$ Stewart and Stuhmcke, above n 32, 278.

${ }^{44}$ Ibid 272.

${ }^{45}$ United Nations Treaty Collection, Databases — Status of Treaties $(2010)<$ http://treaties.un. org/Pages/ViewDetails.aspx?src=UNTSONLINE\&tabid=1\&mtdsg_no=IV-4\&chapter $=4$ \&lang=en\#Participants>.

${ }^{46}$ International Covenant on Civil and Political Rights, opened for signature 16 December 1966, 999 UNTS 171 (entered into force 23 March 1976, except for art 41, which entered into force on 28 March 1979) art 6(5).

${ }^{47}$ See Stewart and Stuhmcke, above n 32, 274.

${ }^{48}$ Australian Human Rights Commission, Fact Sheet 5: International Bill of Rights (2009) $<$ http://www.hreoc.gov.au/education/hr_explained/download/FS5_International.pdf $>$.

49 The General Assembly of the United Nations, Vienna Convention on the Law of Treaties 1969 (entered into force 27 January 1980) art 26, which provides '[e]very treaty in force is binding upon the parties to it and must be performed by them in good faith'.

${ }^{50}$ Dietrich v The Queen (1992) 177 CLR 292, [305] (Mason CJ and McHugh J).
} 
ratified the ICCPR; rather, domestic legislation must be passed to achieve this result. $^{51}$

However, treaties may influence the development of the common law. In Mabo $v$ Queensland (No 2) the High Court of Australia commented that 'international law is a legitimate and important influence on the development of the common law, especially when international law declares the existence of universal human rights'. ${ }^{52}$ Thus, we can see treaties operating to give courts insight into international community values and standards which the courts can use to develop the Australian common law and resolve its inherent ambiguities. $^{53}$

We are perhaps seeing this played out in the evolution of rights for unborn children as a result of biomedical developments. ${ }^{54}$ Such developments have forced a sharp rethink of the 'born alive' rule and whether it is still maintainable that a prenatal child has no right of its own. ${ }^{55}$

Whatever the developments in Australian law with regard to ascribing rights to unborn children, they have not been uniform ${ }^{56}$ and they fall far short of the Ireland model. ${ }^{57}$ Countries such as Ireland have determined that it is worth protecting the lives of unborn children and so have enshrined this protection in their constitutions and given this protection legal effect in their domestic criminal statutes. ${ }^{58}$ Australia's position is that a 'foetus cannot ... have a right of its own ... until it is born and has a separate existence from its mother'. ${ }^{59}$

\footnotetext{
51 Ibid.

${ }^{52}$ Mabo v Queensland (No. 2) (1992) 175 CLR 1, [42] (Brennan J).

${ }^{53}$ See Minister for Immigration and Ethnic Affairs $v$ Teoh (1995) 183 CLR 273, 288-9, 304; Western Australia v Commonwealth (1995) 183 CLR 373, 486-7.

${ }^{54}$ Stewart and Stuhmcke, above n 32, 273.

${ }^{55}$ Ibid 295; see, eg, Fertilitescentrum (sic) AB and Luminis Pty Ltd [2004] APO 19 [31], [37], where the Commissioner, in interpreting the Patents Act 1990 (Cth) s 18(2), claimed that 'human beings' included the prenatal child from conception (at [37]) and the Deputy Commissioner claimed that 'there is no agreement about when in the reproductive process a human being comes into existence' (at [31]); see generally, Paton v British Pregnancy Advisory Service Trustees [1979] QB 276, 279.

${ }^{56}$ Stewart and Stuhmcke, above n 32, 295.

${ }^{57}$ Watt v Rama [1972] VR 353; Constitution of Ireland (Ireland 1937) art 40.3.3.

${ }^{58}$ Constitution of Ireland (Ireland 1937) art 40.3.3; Offences Against the Person Act 1861 (UK) ss 58-9; to demonstrate that Ireland is not alone in its position, see, eg, Constitution of the Republic of the Philippines 1987, art II, s 12, which obliges the state to protect unborn children from conception; Revised Penal Code of the Philippines (Philippines) art 256, which penalises a 'person who shall intentionally cause an abortion'.

${ }^{59}$ Paton v British Pregnancy Advisory Service Trustees [1979] QB 276, 279; Watt v Rama [1972] VR 353.
} 
However, there appears to be a shift in this position, catalysed by recent developments in biomedical science, which are compelling a re-think of this 'born alive' rule. Such a shift has materialised in certain protections for unborn children. ${ }^{60}$ Nevertheless, the law's response in this area has been reactionary, ad hoc, non-uniform and at this stage somewhat rudimentary ${ }^{61}$ certainly a far cry from the definite position of Ireland.

This article concludes that Australia's law offers a measure of protection to an unborn child, but not to the same extent as in other countries such as Ireland. Ireland recognises an unborn child's right to life and has enshrined that right in its Constitution and criminal law. It is fair to say that Australia deems it is worth protecting the lives of unborn children, but the protections that exist are heavily qualified and perhaps undermined by the 'born alive' rule.

\section{EXCEPTIONS TO THE RIGHT TO LIFE FOR UNBORN CHILDREN}

\section{A General Exceptions in Law}

The traditional justification for abortion is necessity. ${ }^{62}$ That is to say abortion is justified in circumstances where it is 'necessary to preserve the woman from a serious danger to her life or her physical or mental health' ${ }^{63}$ So the protection of unborn children is not without limitations.

In common law, the principle of necessity as a defence to a crime is justified on the basis that, on occasions, following the law may bring on greater harm than breaking it. ${ }^{64}$ The basic elements of the defence are that: the criminal act was necessary or at least reasonably believed to have been necessary to avoid or prevent death or serious injury; necessity must be an essential element of the criminal act; and the criminal act was reasonable and proportionate to the harm sought to be avoided. ${ }^{65}$

\footnotetext{
${ }^{60}$ Stewart and Stuhmcke, above n 32, 273-9, 295.

${ }^{61}$ Ibid 295.

${ }^{62}$ See $R v$ Davidson [1969] VR 667; $R v$ Wald [1971] 3 DCR (NSW) 25; see generally Roe $v$ Wade, 410 US 113, 139 (1973).

${ }^{63} R v$ Davidson [1969] VR 667.

${ }^{64} R$ v Loughnan [1981] VR 433, [448]; Simon Bronitt and Bernadette McSherry, Principles of Criminal Law (Thompson Lawbook Co., $2^{\text {nd }}$ ed, 2005) 327-8.

${ }^{65} R v$ Cairns [1999] 2 Crim App Rep 137.
} 
At common law the necessity defence was traditionally available for all crimes except murder. ${ }^{66}$ Whilst this article will not debate the issue of whether or not abortion is murder, the question of whether the defence of necessity can be applied to abortion cases in Australia has been largely answered in the affirmative. $^{67}$ Specifically, the defence of necessity is applicable in determining whether or not therapeutic abortion is lawful. ${ }^{68}$

The issue with using the necessity principle to justify abortion is that the right to life of an unborn child is pitted against the significant health interests of his or her mother. ${ }^{69}$ In such circumstances, society must make its choice on the value of each - the mother and unborn child ${ }^{70}$ - and when it does so, the earlier discussion on the intrinsic value of an unborn child is quite useful. It is plain that the very significant potential value of an unborn child to other human beings ${ }^{71}$ must give way to the actual value of his or her mother when the life of the mother or both is threatened. ${ }^{72}$

It is therefore important that any legal policy underpinning the criminalisation of abortion incorporates the law of necessity. Where the mother's life or her physical or mental health is in serious danger, therapeutic abortion is justified based on necessity. ${ }^{73}$ With this position stated, it is useful to examine and contrast the current laws in Australia justifying abortion.

\section{B Specific Exceptions for the Protection of Pregnant Women}

The 1969 Victorian case of $R v$ Davidson ${ }^{74}$ is of particular significance in this discussion because it established the legal principle by which abortions proscribed under law could be justified. The case concerned a criminal prosecution under s 65 of the Crimes Act 1958 (Vic) ${ }^{75}$ for a therapeutic

\footnotetext{
${ }^{66} R v$ Dudley and Stephens (1884) 14 QBD 27; $R v$ Howe [1987] AC 417.

${ }^{67}$ See $R v$ Davidson [1969] VR 667; $R v$ Wald [1971] 3 DCR (NSW) 25.

${ }^{68} R v$ Davidson [1969] VR 667.

${ }^{69}$ Roe $v$ Wade, 410 US 113, 150 (1973).

${ }^{70}$ See generally Roe $v$ Wade, 410 US 113, 150-2 (1973).

${ }^{71}$ Dworkin, above n 4, 12-3; see generally Roe v Wade, 410 US 113, 159, 162 (1973).

${ }^{72}$ Roe $v$ Wade, 410 US 113, 150 (1973).

${ }^{73} R v$ Davidson [1969] VR 667; $R v$ Wald [1971] 3 DCR (NSW) 25.

${ }^{74}$ [1969] VR 667.

${ }^{75}$ Crimes Act 1958 (Vic) s 65 provided that '[w] hosoever with intent to procure the miscarriage of any woman whether she is or is not with child unlawfully administers to her or causes to be taken by her any poison or other noxious thing, or unlawfully uses any instrument or other means with the like intent, shall be guilty of a felony ...'.
} 
abortion. In dealing with that case, the Court established the basis on which abortions could be carried out without offending the law. The court ruled that to determine whether or not a therapeutic abortion is lawful under section $65:^{76}$

[T]he principle to be applied is the principle of necessity, importing the elements of necessity and proportion to the mischief to be prevented and the requirement of honest belief on reasonable grounds on the part of the accused that his act was necessary. ${ }^{77}$

That is, to lawfully terminate a pregnancy, a doctor must reasonably believe that such an operation is necessary to "preserve the woman from serious danger to her life or her physical or mental health' ${ }^{78}$ Significantly, the court held that the relevant dangers need not be 'the normal dangers of pregnancy and childbirth', but include other physical and mental factors which could jeopardise the woman's health. ${ }^{79}$ The significance of this last part of Menhennitt J's ruling is evident when it is contrasted with a tragic case in Ireland.

In 1992, an Irish abortion case captured international attention and aroused debate. ${ }^{80}$ The case concerned a 14 year old rape victim who conceived from the rape and was prevented from travelling to the United Kingdom (UK) to obtain an abortion. ${ }^{81}$ The Irish Attorney-General obtained an interim injunction in the Irish High Court to prevent the girl from leaving Ireland on the grounds that this would protect the unborn child's right to life. ${ }^{82}$ However, the pregnancy posed a serious risk to the young mother's life; she was suicidal as a result of the pregnancy. ${ }^{83}$ The controversy surrounding the case centred on the competing rights of the unborn child and mother - the unborn child's right to life versus the mother's right to be rid of the mental stress of the pregnancy that was endangering her life. ${ }^{84}$ Amidst the controversy, the Irish Supreme Court eventually lifted the injunction as a result of the efforts of the young mother's family. ${ }^{85}$ This Irish case stands in stark contrast to the

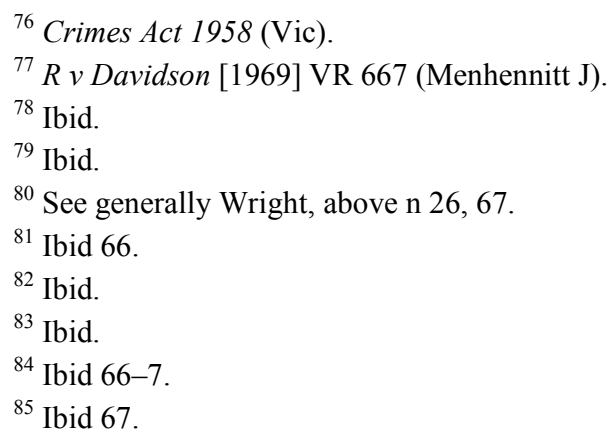


Australian case, and highlights the very sensible balance the court in $R v$ Davidson ${ }^{86}$ achieved when resolving the problem of the competing interests of unborn child and mother. If the Irish court had applied the principles set out in $R v$ Davidson ${ }^{87}$ it can be concluded that the Irish case would have been quickly settled in favour of the young mother. An abortion is not a frivolous matter - it is an act that should be considered only when necessity dictates, and such necessity would have been deemed to have arisen in the circumstances of the young Irish rape victim plagued with suicidal tendencies due to her pregnancy.

Whilst Victoria legalised abortion in $2008,{ }^{88}$ the $R v$ Davidson ${ }^{89}$ judgment concerning the principle of necessity is nevertheless very persuasive in other jurisdictions such as Queensland and New South Wales (NSW) when these jurisdictions apply their respective criminal statutes on abortion. ${ }^{90}$ In the NSW case of $R v \mathrm{Wald}^{91}$ the principle of necessity - as applied to abortion cases per $R v$ Davidson $^{92}$ — was followed and its focus sharpened by Levine DCJ. Levine DCJ elaborated on the scope of the test by commenting that:

[I]t would be for the jury to decide whether there existed in the case of each woman any economic, social or medical ground or reason which in their view could constitute reasonable grounds upon which an accused could honestly and reasonably believe there would result a serious danger to her mental or physical health. It may be that an honest belief be held that the woman's mental health, although not then in serious danger, could reasonably be expected to be seriously endangered at some time during the currency of the pregnancy. ${ }^{93}$

The contrast between this decision and the aforementioned Irish case is quite stark. In that case, reasoning of the kind used in $R v$ Wald $^{94}$ would clearly

\footnotetext{
${ }^{86}$ [1969] VR 667.

${ }^{87}$ Ibid.

${ }^{88}$ Abortion Law Reform Act 2008 (Vic) ss 1, 4-5, which repeals the crime of abortion and permits abortions to be carried out up to 24 weeks into the pregnancy (and beyond that period with the approval of two doctors).

${ }^{89}$ [1969] VR 667.

${ }^{90} R v$ Bayliss and Cullen (1986) 9 Qld Lawyer Reps 8, 30, 45; $R v$ Wald [1971] 3 DCR (NSW) 25; Heather Douglas, 'Abortion Reform: A State Crime or a Woman's Right to Choose?' (2009) 33(2) Criminal Law Journal 74, 76-8.

${ }^{91}$ [1971] 3 DCR (NSW) 25.

92 [1969] VR 667.

${ }^{93} R v$ Wald [1971] 3 DCR (NSW) 25, 29; see also CES $v$ Superclinics (Australia) Pty Ltd (1995) 38 NSWLR 47 ('Superclinics'), in which members of the NSW Court of Appeal endorsed the decision in Wald.

${ }^{94}$ [1971] 3 DCR (NSW) 25.
} 
accommodate the wishes of the young mother and her family in view of the young mother's risk of suicide. Yet $R v$ Wald $^{95}$ still keeps intact the principle of necessity when determining the circumstances under which an abortion is permissible. ${ }^{96}$

This article strongly advocates the use of the principle of necessity as a legal 'safety valve', so that abortions are permitted only under the particular conditions stipulated by Menhennitt J and Levine DCJ. ${ }^{97}$ These conditions provide an effective test by which the rights and needs of pregnant women can be properly balanced against the right to life of unborn children and thereby ensure that abortions take place for serious and not frivolous reasons.

By way of illustration, to highlight how a treatable minor medical problem could be used to justify an abortion, it is worth mentioning a recent Italian abortion incident that has attracted pointed criticism. In this incident, a 22 week old infant was found breathing and left by doctors to die in an Italian hospital after a botched abortion operation. ${ }^{98}$ The child was discovered alive some 20 hours after the abortion operation by the hospital chaplain who raised the alarm. ${ }^{99}$ The child died the following day in intensive care. ${ }^{100}$ The poignant fact in this incident is that the first time pregnant mother opted for the abortion after discovering the unborn child had a cleft lip and palate - a condition that could be effectively treated by surgery. ${ }^{101}$ The circumstances of this tragic incident highlight the need to ensure that the principle of necessity is the guiding legal principle in controlling when it is appropriate for an abortion to take place; this legal principle will ensure that the intrinsic value of unborn children and their right to life are not seriously undermined by allowing abortions for trivial reasons.

\footnotetext{
95 Ibid.

${ }^{96}$ Ibid.

${ }^{97}$ See $R$ v Davidson [1969] VR 667; ibid.

${ }^{98}$ Simon Caldwell, 'Baby that Survived Botched Abortion was Rejected for Cleft Lip and Palate', The Telegraph (online), 29 April $2010<$ http://www.telegraph.co.uk/news/ worldnews/europe/italy/7652889/Baby-that-survived-botched-abortion-was-rejected-for-cleftlip-and-palate.html>.

${ }^{99}$ Ibid.

100 Ibid.

${ }^{101}$ Ibid.
} 


\section{Criminal LaW in Australia Dealing With ABORTION}

\section{A Jurisdictions Promoting Choice for Pregnant Women}

There are three Australian jurisdictions that currently promote choice for pregnant women with regard to abortion. ${ }^{102}$ This article will deal with two Victoria and the ACT. These two are sufficient for the purpose of determining whether or not the criminal law across Australian jurisdictions on the subject of abortion lacks sufficient effective uniformity to properly safeguard unborn children. ${ }^{103}$ Western Australia, the third jurisdiction, was the first to reform abortion law in 1998 in favour of a pro-choice position. ${ }^{104}$ It is perhaps more worthwhile, therefore, to look at the two more recent abortion law reforms in Victoria and the ACT. ${ }^{105}$ After all, legislators in these jurisdictions considered the Western Australian model in formulating their own reforms. ${ }^{106}$

\section{$1 \quad$ Victoria}

Victoria has relatively recently (in 2008) reversed its position on the criminality of abortion by replacing its 'pro-life' stance with a 'pro-choice' stance. ${ }^{107}$ This shift may be in tune with community attitudes, ${ }^{108}$ but it is a

102 See generally Victorian Law Reform Commission, Law of Abortion, Final Report No 15 (2008) 16-24

103 See, eg, Criminal Code Act 1899 (Q1d) ss 224-6, which prescribes when it is illegal to procure a miscarriage; Abortion Law Reform Act 2008 (Vic) ss 1, 4-5, which repeals the crime of abortion and permits abortions to be carried out up to 24 weeks into the pregnancy (and beyond that period with the approval of two doctors); Elizabeth Kennedy, 'Abortion Laws in Australia' (2007) 9(4) $O \&$ \& Magazine 36, 36-7. This paper will contend that only one prochoice jurisdiction is needed to undermine the fabric of protection for unborn children - see generally Kennedy, above n 103, 37.

${ }^{104}$ Mark J Rankin, 'Contemporary Australian Abortion Law: The Description of a Crime and the Negation of a Woman's Right to Abortion' (2001) 27(2) Monash University Law Review 229, 246; Criminal Code Compilation Act 1913 (WA) s 199, which permits an abortion if it is performed by a medical practitioner and justified under the Health Act 1911 (WA) s 334, and such justification includes where the pregnant woman has given informed consent for the abortion and her unborn child is less than 20 weeks old - see Health Act 1911 (WA) ss 334(3)(a), (7).

105 These reforms took place in 2008 and 2002 respectively; see Abortion Law Reform Act 2008 (Vic); Crime (Abolition of Offence of Abortion) Act 2002 (ACT).

${ }^{106}$ Victorian Law Reform Commission, above n 102, 23-4.

${ }^{107}$ Victoria, Parliamentary Debates, Legislative Council, 12 September 2008, 3792-5 (Gavin Jennings) 3792-3; Victoria, Parliamentary Debates, Legislative Assembly, 19 August 2008, 2950-6 (Maxine Morand) 2950-2. 
shift that subjects the right to life of unborn children to the discretion of their mothers. ${ }^{109}$ This article contends that it is the duty of the Victorian government $-\mathrm{a}$ duty to protect the voiceless and vulnerable ${ }^{110}$ — to stand firm in the protection of the lives of unborn children in any trimester ${ }^{111}$ and under any circumstances other than the aforementioned exceptions. ${ }^{112}$

Prior to the introduction of the Abortion Law Reform Act 2008 (Vic), Victoria's criminal law regime adequately promoted the right to life for unborn children. Prior to its changes, the Crimes $A c t^{113}$ held that abortion was an indictable offence punishable by significant periods of imprisonment. ${ }^{114}$ Section $65^{115}$ provided:

Whosoever being a woman with child with intent to procure her own miscarriage unlawfully administers to herself any poison ... or unlawfully uses any instrument ... and whosoever with intent to procure the miscarriage of any woman ... unlawfully administers to her ... any poison $\ldots$ or unlawfully uses any instrument $\ldots$ shall be guilty of an indictable offence. $^{116}$

\footnotetext{
${ }^{108}$ Victorian Law Reform Commission, above n 102, 65.

${ }^{109}$ Victoria, Parliamentary Debates, Legislative Assembly, 19 August 2008, 2950-6 (Maxine Morand) 2952.

${ }^{110}$ Roe $v$ Wade, 410 US 113, 150 (1973) regarding the state's interest and duty in protecting prenatal life.

${ }^{111}$ Dworkin, above n 4, 12-3; see also International Covenant on Civil and Political Rights, opened for signature 16 December 1966, 999 UNTS 171 (entered into force 23 March 1976, except for art 41, which entered into force on 28 March 1979) art 24(1), which provides that '[e]very child shall have, without any discrimination as to race, colour, sex, language, religion, national or social origin, property or birth, the right to such measures of protection as are required by his status as a minor, on the part of his family, society and the State'. Whilst this provision explicitly applies to postnatal children, it indicates an international willingness to protect the rights of the vulnerable, which may extend - at least in the future - to prenatal children. Note that Australia is a party to the ICCPR after ratifying it on 13 August 1980; see Dietrich v The Queen (1992) 177 CLR 292, [8] (Mason CJ and McHugh J).

${ }^{112}$ See Part III of this article.

1131958 (Vic).

${ }^{114}$ Crimes Act 1958 (Vic) ss 10 (which was later repealed by the Abortion Law Reform Act 2008 (Vic) s 9), 65-6 (both later substituted with new provisions by the Abortion Law Reform Act 2008 (Vic) s 11); see also Victorian Law Reform Commission, above n 102, 16-8. Note that the Crimes Act 1958 (Vic) s 10 will not be discussed in this article because the section overlaps with s 65; see Victorian Law Reform Commission, above n 102, 18.

${ }^{115}$ Crimes Act 1958 (Vic), later substituted by Abortion Law Reform Act 2008 (Vic) s 11.

${ }^{116}$ Crimes Act 1958 (Vic) s 65, later replaced by Abortion Law Reform Act 2008 (Vic) s 11.
} 
The question of what was 'unlawful' was not answered in the Act; ${ }^{117}$ instead, the legislation left it to the courts to determine the circumstances that render an intentional abortion unlawful, or, conversely, lawful. ${ }^{118}$ Section 66 provided that $[\mathrm{w}]$ hosover unlawfully supplies ... any poison ... or any instrument ... knowing that the same is intended to be unlawfully used ... with intent to procure the miscarriage of any woman ... shall be guilty of an indictable offence'. ${ }^{119}$ Again, what constituted 'unlawfully' in this section was left for the courts to decide. ${ }^{120}$ Both of these sections proscribe unlawful termination of pregnancy throughout all stages of pregnancy. ${ }^{121}$

The question of what constitutes 'unlawfully' in the context of sections 65 and $66^{122}$ was discussed above ${ }^{123}$ in relation to the cases of $R v$ Davidson $^{124}$ and $R$ $v$ Wald ${ }^{125}$ Very briefly, in $R v$ Davidson, ${ }^{126}$ Justice Menhennitt laid down the circumstances in which a therapeutic abortion would be deemed lawful and such circumstances were based on the principle of necessity. ${ }^{127}$ In the NSW case of $R v$ Wald, ${ }^{128}$ Levine DCJ elaborated on Menhennitt J's ruling by setting out matters - such as the social and economic circumstances of the mother - that a doctor could consider when properly determining whether the principle of necessity would apply to justify an abortion. ${ }^{129}$ Whilst the $R v$ Wald $^{130}$ decision was never binding on Victorian courts, it was nonetheless persuasive due to the similarities that existed at the time between the Victorian and NSW criminal statutes dealing with abortion. ${ }^{131}$

\footnotetext{
117 Crimes Act 1958 (Vic).

${ }^{118}$ Victorian Law Reform Commission, above n 102, 17.

${ }^{119}$ Crimes Act 1958 (Vic) s 66, later replaced by Abortion Law Reform Act 2008 (Vic) s 11.

${ }^{120}$ Victorian Law Reform Commission, above n 102, 17.

${ }^{121}$ Victoria, Parliamentary Debates, Legislative Assembly, 19 August 2008, 2950-6 (Maxine Morand) 2950; ibid 16-7.

${ }^{122}$ Crimes Act 1958 (Vic), later replaced per Abortion Law Reform Act 2008 (Vic) s 11.

${ }^{123}$ That is, in Part IIIB of this article.

${ }^{124}$ [1969] VR 667.

125 [1971] 3 DCR (NSW) 25.

126 [1969] VR 667.

${ }^{127}$ See $R$ v Davidson [1969] VR 667; Victorian Law Reform Commission, above n 102, 19.

${ }^{128}$ [1971] 3 DCR (NSW) 25.

129 Ibid.

130 Ibid.

${ }^{131}$ That is, prior to the introduction of the Abortion Law Reform Act 2008 (Vic); Victorian Law Reform Commission, above n 102, 20.
} 
Prior to the 2008 amendments, the Crimes $A c t^{132}$ implicitly recognised the intrinsic value of human life from the moment of its conception. It did so through proscribing abortion during any stage of a pregnancy. ${ }^{133}$ The Crimes $A c t^{134}$ also implicitly recognised the right to life of unborn children - a right that was protected through criminal sanction for those intending to injure that right. ${ }^{135}$ Whilst the Crimes Act ${ }^{136}$ did not directly deal with circumstances justifying abortion, the courts drew on the principle of necessity in describing such circumstances. ${ }^{137}$ By all measures, it would seem that the criminal law in Victoria prior to its amendment in 2008 had the necessary elements to promote the right to life for unborn children. However, in 2008 this legislative and case law regime protecting unborn children dissipated with the passing of the Abortion Law Reform Act. ${ }^{138}$

The Abortion Law Reform Act ${ }^{139}$ has the effect of subjecting the right to life of unborn children to the discretion of their mothers. ${ }^{140}$ Section $11^{141}$ replaces the abortion offences under the Crimes $A c t^{142}$ with new provisions. Section $65^{143}$ now provides that it is only illegal for 'unqualified persons' to perform an abortion. ${ }^{144}$ Section $65(2)^{145}$ explicitly states that a pregnant woman who consents to or assists in the carrying out of an abortion on herself by an unqualified person is not guilty of an offence under the section. ${ }^{146}$ Section $66^{147}$ now provides that common law offences concerning abortion are abolished. ${ }^{148}$ Section $4{ }^{149}$ provides that a doctor can perform an abortion on a

1321958 (Vic) ss 65-6, later replaced per Abortion Law Reform Act 2008 (Vic) s 11.

${ }^{133}$ See Victorian Law Reform Commission, above n 102, 16-7.

${ }^{134} 1958$ (Vic) ss 65-6, later replaced per Abortion Law Reform Act 2008 (Vic) s 11.

${ }^{135}$ See Victorian Law Reform Commission, above n 102, 16-8.

${ }^{136}$ Crimes Act 1958 (Vic) ss 65-6, later replaced per Abortion Law Reform Act 2008 (Vic) s 11.

${ }^{137}$ See $R v$ Davidson [1969] VR 667; $R v$ Wald [1971] 3 DCR (NSW) 25.

${ }^{138} 2008$ (Vic).

1392008 (Vic).

140 See Victoria, Parliamentary Debates, Legislative Council, 12 September 2008, 3792-5 (Gavin Jennings) 3793.

${ }^{141}$ Abortion Law Reform Act 2008 (Vic).

1421958 (Vic) ss 65-6.

${ }^{143}$ Crimes Act 1958 (Vic).

${ }^{144}$ Crimes Act 1958 (Vic) s 65(1), with s 65(3) specifying that a registered medical practitioner is a qualified person, and registered pharmacists and nurses are qualified to administer drugs, etc for the purpose of an abortion.

${ }^{145}$ Crimes Act 1958 (Vic).

${ }^{146}$ Crimes Act 1958 (Vic) s 65(1).

${ }^{147}$ Crimes Act 1958 (Vic).

148 This paper will briefly discuss the effect of common law on abortion under Part IVB of this article - 'Jurisdictions Promoting Protection for Unborn Children'. 
woman who is not more than 24 weeks pregnant. All these statutory provisions make it possible for a woman not more than 24 weeks pregnant to get an abortion for any reason whatsoever, without any regard to the intrinsic value of the child she is carrying or the unborn child's right to life, or any concern for the proportionality of her actions, a proportionality that would bear on the principle of necessity. ${ }^{150}$

Victoria's shift in 2008 towards supporting the 'pro-choice' position by legalising abortion was driven by community attitudes calling for women to 'have unrestricted access to abortion on demand" ${ }^{\text {'51 }}$ and for there to be 'legal certainty on the circumstances in which an abortion is legal'. ${ }^{152}$ Notwithstanding community values, it is this article's contention that the Victorian government should not have wilted in the face of 'pro-choice' community sentiments, but should have instead stood firm in its opposition to abortions that are undertaken for frivolous reasons. The law as it stands now in Victoria renders the life of an unborn child virtually worthless when pitted against the wide discretion of the child's mother.

Interestingly, public sentiments ${ }^{153}$ also expressed the view that abortions should not be carried out after 20 weeks of pregnancy for non-medical reasons, that is, for reasons such as financial or emotional stress. ${ }^{154}$ This demonstrates that the community places significant value on an unborn child in an advanced state of development. However, to fix a point in time in which a foetus has merited protection by virtue of its supposed development has very little scientific basis and represents no more than a legal fiction. ${ }^{155}$ How can one say that a foetus at 19 weeks can be aborted at the mother's discretion whilst a foetus at 20 weeks can be aborted only where necessity arises? Can society fix a time when a foetus first makes a detectable movement in the womb, ${ }^{156}$ when a foetus is 'viable', ${ }^{157}$ when a child first speaks, first walks,

149 Abortion Law Reform Act 2008 (Vic).

150 See Victoria, Parliamentary Debates, Legislative Council, 12 September 2008, 3792-5 (Gavin Jennings) 3793.

${ }^{151}$ Victorian Law Reform Commission, above n 102, 60.

152 Victoria, Parliamentary Debates, Legislative Council, 12 September 2008, 3792-5 (Gavin Jennings) 3793.

${ }^{153}$ As expressed in the Victorian Law Reform Commission, above n 102, 58-68.

${ }^{154}$ Ibid 66.

${ }^{155}$ Stewart and Stuhmcke, above n 32, 272; Tremblay v Daigle [1989] 2 SCR 530, 553.

156 That is, is 'quick'. See Roe $v$ Wade, 410 US 113, 132 (1973) for a description of 'quickening', which is 'the first recognisable movement of the foetus in utero'.

${ }^{157}$ That is, when the unborn child is capable of being born alive. See Mark J Rankin, 'Recent Developments in Australian Abortion Law: Tasmania and the Australian Capital Territory' (2003) 29(2) Monash University Law Review 316, 331. 
first progresses out of nappies, or first reads? These are all developmental phases that cannot be properly fixed in time. ${ }^{158}$ So community views that hold a foetus to be more valuable (and thus more useful to society) at a particular point in time are bound to be contentious; ${ }^{159}$ the better approach is to recognise the intrinsic value of an unborn child from conception ${ }^{160}$ and apply the principle of necessity to govern when abortions are permissible during any point of the pregnancy. ${ }^{161}$

Unfortunately, the law in Victoria is far from ideal in this regard. Section $5^{162}$ provides that a foetus of more than 24 weeks cannot simply be aborted at the private discretion of its mother. ${ }^{163}$ Instead, a pregnant woman wishing to abort her unborn child after 24 weeks of pregnancy is required to have approval from two doctors who reasonably believe 'the abortion is appropriate in all the circumstances'. ${ }^{164}$ In determining what is appropriate in all the circumstances, the doctor must have regard to 'all relevant medical circumstances" ${ }^{165}$ and 'the woman's current and future physical, psychological and social circumstances'. ${ }^{166}$ These provisions place limits on a woman's discretion to abort her unborn child during pregnancy ${ }^{167}$ and they reflect - in the case of unborn children of more than 24 weeks - the sentiments expressed in $R v$ Davidson $^{168}$ and $R v$ Wald $^{169}$ where abortion is justified only by reason of necessity. ${ }^{170}$ The problem with this stance is that it creates an artificial distinction between when an unborn child is merely a part of a woman's body and when he or she is of sufficient worth to warrant state protection. ${ }^{171}$ Such a distinction fails to recognise and respect the intrinsic value of an unborn child

158 Child Development Institute, Normal Stages of Human Development (Birth to 5 Years) (2010) <http://www.childdevelopmentinfo.com/development/normaldevelopment.shtml >; ibid.

${ }^{159}$ Roe $v$ Wade, 410 US 113, 159-61 (1973).

${ }^{160}$ Dworkin, above n 4, 11-3.

${ }^{161} R v$ Davidson [1969] VR 667; $R v$ Wald [1971] 3 DCR (NSW) 25.

162 Abortion Law Reform Act 2008 (Vic).

${ }^{163}$ Victoria, Parliamentary Debates, Legislative Council, 12 September 2008, 3792-5 (Gavin Jennings) 3793.

${ }^{164}$ Abortion Law Reform Act 2008 (Vic) s 5(1).

165 Ibid s 5(2)(a).

${ }^{166}$ Ibid s 5(2)(b).

${ }^{167}$ Victoria, Parliamentary Debates, Legislative Council, 12 September 2008, 3792-5 (Gavin Jennings) 3794.

${ }^{168}$ [1969] VR 667.

169 [1971] 3 DCR (NSW) 25.

${ }^{170} R$ v Davidson [1969] VR 667; ibid; Victorian Law Reform Commission, above n 102, 90.

${ }^{171}$ See generally Stewart and Stuhmcke, above n 32, 272; Tremblay v Daigle [1989] 2 SCR 530, 553. 
from conception and to afford him or her the necessary protection he or she deserves when in a vulnerable condition throughout the whole prenatal period.

This article contends that the better approach would have been to apply the same protection given to a foetus of more than 24 weeks to a foetus of up to 24 weeks. The reality is that less than one per cent of abortions take place after 20 weeks of pregnancy. ${ }^{172}$ Therefore, to provide a safeguard akin to the principle of necessity for a foetus of more than 24 weeks is of some value, but would not prevent the majority of abortions. Over 99 per cent of unborn children who are at risk of being aborted will receive no protection from the state (that is, Victoria in this case). ${ }^{173}$ The position in Victoria is quite stark the criminal law currently fails to promote the right to life for unborn children.

\section{$2 \quad$ Australian Capital Territory}

The Australian Capital Territory (ACT) was the first Australian jurisdiction to decriminalise abortion. ${ }^{174}$ This occurred in 2002 when the ACT instituted the most liberal laws in Australia in advancement of the pro-choice agenda. ${ }^{175}$ The passing of the Crime (Abolition of Offence of Abortion) Act 2002 (ACT) repealed all statutory and common law offences of abortion in the ACT, and now abortion is regulated in the ACT in the same manner as any other medical procedure. ${ }^{176}$

Prior to its decriminalisation, abortion in the ACT was a crime, as it was in Victoria, NSW and Queensland. ${ }^{177}$ Under the Crimes Act 1900 (ACT), ${ }^{178}$ abortion was a serious crime with severe penalties. ${ }^{179}$ Notwithstanding the seriousness of the offence of abortion, it was generally held that exceptions

\footnotetext{
${ }^{172}$ Victoria, Parliamentary Debates, Legislative Council, 12 September 2008, 3792-5 (Gavin Jennings) 3793; Victorian Law Reform Commission, above n 102, 36.

${ }^{173}$ Victorian Law Reform Commission, above n 102, 36; Abortion Law Reform Act 2008 (Vic) s 5 .

${ }^{174}$ Kennedy, above n 103, 37; Victorian Law Reform Commission, above n 102, 24; Crime (Abolition of Offence of Abortion) Act 2002 (ACT).

${ }^{175}$ Rankin, 'Recent Developments in Australian Abortion Law', above n 158, 327.

${ }^{176}$ Victorian Law Reform Commission, above n 102, 24.

177 Rankin, Recent Developments in Australian Abortion Law', above n 158, 327. The latter two jurisdictions will be discussed later under Part IVB.

${ }^{178}$ Crimes Act 1900 (ACT) ss 44-6.

${ }^{179}$ Rankin, 'Recent Developments in Australian Abortion Law', above n 158, 327.
} 
grounded in the principle of necessity, discussed in $R v$ Davidson $^{180}$ and $R v$ Wald $^{181}$ regulated the permissibility of abortions in the ACT. ${ }^{182}$

It can be said that the ACT had a very robust legal regime to safeguard the lives of unborn children - a regime that permitted abortion only under circumstances of necessity where the health of the mother was at serious risk. ${ }^{183}$ This safeguard was further bolstered by the operation of the Health Regulation (Maternal Information) Act 1998 (ACT); this Act provided that women wishing to access abortion in circumstances of necessity must be provided with information regarding foetal development ${ }^{184}$ and the medical risks associated with an abortion. ${ }^{185}$ The main purpose of the compulsory provision of this information was to ensure that a woman's decision to abort her child was carefully considered with particular and implicit regard to the impact that the abortion would have on the life growing inside her. ${ }^{186}$ However, the Act's ${ }^{187}$ provisions also served to delay the process of obtaining an abortion. ${ }^{188}$ Taken together, the Crimes Act 1900 (ACT) ${ }^{189}$ and the Health Regulation (Maternal Information) Act 1998 (ACT) provided a solid foundation for the protection of the right to life of unborn children in the ACT.

This solid regime of protection for unborn children was stripped almost bare in 2002 when the ACT repealed not only the criminal provisions concerning abortion, ${ }^{190}$ but also the Health Regulation (Maternal Information) Act 1998 (ACT). ${ }^{191}$ The only remaining protection for unborn children sets in at the

\footnotetext{
${ }^{180}$ [1969] VR 667.

${ }^{181}$ [1971] 3 DCR (NSW) 25. Such exceptions are discussed in detail under Part IIIB of this article.

${ }^{182}$ Rankin, 'Recent Developments in Australian Abortion Law', above n 158, 327.

183 See ibid.

${ }^{184}$ Health Regulation (Maternal Information) Act 1998 (ACT) s 8(1)(a)(iv).

${ }^{185}$ Ibid s 8(1)(a)(i)-(iii).

186 Ibid s 3(b); Rankin, 'Recent Developments in Australian Abortion Law', above n 158, 327-8.

${ }^{187}$ Health Regulation (Maternal Information) Act 1998 (ACT).

${ }^{188}$ Ibid s 10(a), which provides a mother cannot undertake an abortion before a minimum 72 hours waiting period to contemplate the information provided to her per s 8(a).

${ }^{189}$ Crimes Act 1900 (ACT) ss 44-6.

${ }^{190}$ Crimes (Abolition of Offence of Abortion) Act 2002 (ACT) ss 3, 44.

${ }^{191}$ Health Regulation (Maternal Information) Repeal Act 2000 (ACT); see Rankin, 'Recent Developments in Australian Abortion Law', above n 158, 329.
} 
point the foetus attains 'viability'. ${ }^{192}$ Under the Crimes Act 1900 (ACT) section 42, it is an offence to commit 'child destruction', which occurs 'when a person unlawfully prevents a child from being born alive'. ${ }^{193}$ This provision is interpreted as applying only to a viable foetus or one that is capable of being born alive. ${ }^{194}$ The definition of 'unlawful' is found in $R v$ Wald $^{195}$ and it applies in circumstances where the termination of the viable foetus takes place for reasons other than necessity. ${ }^{196}$ The problem with this 'protection' is the lack of precision concerning when during the pregnancy it becomes operative. ${ }^{197}$ With ongoing advances in medical technology and practice, the point of viability is constantly shifting. ${ }^{198}$ The collective conclusions of parliaments and courts in various Australian jurisdictions on this subject indicate that the point of viability ranges between 22 and 28 weeks of pregnancy. ${ }^{199}$ Therefore, uncertainty as to viability coupled with the fact that over 99 per cent of abortions take place prior to 20 weeks of pregnancy ${ }^{200}$ renders this provision ${ }^{201}$ virtually useless and therefore leaves the right to life of unborn children in the ACT with virtually no protection.

The situation as it stands in the ACT is such that the lives of unborn children are essentially subject to the discretion of their mothers. The law fails to recognise the intrinsic value of human life from its conception and fails to afford it any proper protection. From the perspective of an unborn child's interests, the ACT in 2002 had taken a quantum leap backwards from a position previously supportive of an unborn child's right to life. Indeed, '[t]he ACT has lighted the way towards abortion being a right, and ... taken a crucial step towards ... the feminist utopia'. ${ }^{202}$ Together, Victoria and the

\footnotetext{
192 That is, the point at which the foetus becomes capable of being born alive. See Rankin, 'Recent Developments in Australian Abortion Law', above n 158, 331; Crimes Act 1900 (ACT) s 42.

${ }^{193}$ Victorian Law Reform Commission, above n 102, 24.

${ }^{194}$ Rankin, 'Recent Developments in Australian Abortion Law', above n 158, 331.

195 [1971] 3 DCR (NSW) 25; see ibid 327.

${ }^{196}$ See $R v$ Davidson [1969] VR 667; $R v$ Wald [1971] 3 DCR (NSW) 25, which followed $R v$ Davidson and elaborated on the principle of necessity.

${ }^{197}$ Rankin, 'Recent Developments in Australian Abortion Law', above n 158, 331.

${ }^{198}$ Ibid.

${ }^{199}$ Ibid.

${ }^{200}$ Victorian Law Reform Commission, above n 102, 36.

${ }^{201}$ Crimes Act 1900 (ACT) s 42.

${ }^{202}$ Rankin, 'Recent Developments in Australian Abortion Law', above n 158, 335.
} 
ACT represent a 'gaping hole' in the protection of an unborn child's life in Australia, an issue that will be discussed later in this article. ${ }^{203}$

\section{B Jurisdictions Promoting Protection for Unborn Children}

There are five Australian jurisdictions that currently promote an unborn child's right to life. ${ }^{204}$ The two that this article will focus on are NSW and Queensland, for the reason that judicial decisions in these States have tested the respective abortion crime provisions. ${ }^{205}$ The other three jurisdictions are the Northern Territory, Tasmania and South Australia. ${ }^{206}$

However, before looking at specific jurisdictions, it is worth first looking at the position of the common law with regard to abortion. After all, the two prochoice jurisdictions discussed earlier - Victoria and the ACT - deemed it necessary to ensure that their respective abortion law reform legislation specifically repealed common law abortion offences. ${ }^{207}$

\section{Common Law Protection of Unborn Children}

The common law's regulation of abortion is somewhat unclear ${ }^{208}$ due to the fact that abortion has been governed by the operation of statutes since as early as 1803 in England. ${ }^{209}$ However, it appears certain that an abortion after quickening is a common law offence. ${ }^{210}$ That is, the termination of a foetus from the moment of its first recognisable movement in the womb ${ }^{211}$ is

\footnotetext{
${ }^{203}$ That is, under Part IVC of this article.

${ }^{204}$ See generally Victorian Law Reform Commission, above n 102, 21-4.

${ }^{205}$ Ibid. Note that a number of the cases to be discussed are jury trials and they are limited in what they provide in the way of 'reasons for deciding'.

${ }^{206}$ Ibid 22-4.

${ }^{207}$ Crimes Act 1958 (Vic) s 66, as replaced by Abortion Law Reform Act 2008 (Vic) s 11; Crimes (Abolition of Offence of Abortion) Act 2002 (ACT) s 44(1).

${ }^{208}$ Victorian Law Reform Commission, above n 102, 24; see also Roe v Wade, 410 US 113, 135-6 (1973).

${ }^{209}$ Victorian Law Reform Commission, above n 102, 24.

210 Louis Waller 'Any Reasonable Creature in Being' (1987) 13 Monash University Law Review 37, 38; but see Roe $v$ Wade, 410 US 113, 134-5 (1973).

${ }^{211}$ Roe $v$ Wade, 410 US 113, 132 (1973), which holds that quickening is 'the first recognisable movement of the fetus in utero, appearing usually from the $16^{\text {th }}$ to the $18^{\text {th }}$ week of pregnancy'.
} 
unlawful under common law. ${ }^{212}$ However, the termination of a foetus prior to quickening appears not to be proscribed under common law. ${ }^{213}$

The common law, where it operates, provides a two tiered approach to abortion - permitting the abortion of a pre-quickened foetus and proscribing the abortion of a quickened foetus. ${ }^{214}$ Such an approach fails to adequately protect the right to life of unborn children, especially given the fact that the large majority of abortions take place early in pregnancy before quickening. ${ }^{215}$ This approach is also one fraught with uncertainty due to the fact that 'quickening' is an occurrence that cannot be properly fixed to a point in the pregnancy period. ${ }^{216}$ For these reasons, the common law is not an adequate safeguard of the right to life of unborn children.

However, it was England's first abortion statute in 1803 that first prohibited the abortion of a pre-quickened foetus. ${ }^{217}$ This article will now turn to how effectively contemporary Australian statutes safeguard the right to life of unborn children.

\section{$2 \quad$ New South Wales}

In NSW, abortion is ostensibly unlawful. ${ }^{218}$ That is, whilst the NSW criminal law proscribes abortion, ${ }^{219}$ case law has opened the gate for abortions to occur through its liberal interpretation of what circumstances justify an abortion. ${ }^{220}$ NSW case law also demonstrates that the notion of a 'lawful abortion' is

\footnotetext{
${ }^{212}$ Waller, above n 214, 38; see also ibid 134-5.

${ }^{213} R$ (on the application of Smeaton) $v$ Secretary of State for Health [2002] EWHC 610 [83]; Roe $v$ Wade, 410 US 113, 132-3 (1973); see generally Victorian Law Reform Commission, above $\mathrm{n} 102,24$.

${ }^{214} R$ (on the application of Smeaton) $v$ Secretary of State for Health [2002] EWHC 610 [83].

${ }^{215}$ Victorian Law Reform Commission, above $\mathrm{n} 102,36$ where it is found that $94.6 \%$ of abortions take place before 13 weeks of pregnancy; Roe $v$ Wade, 410 US 113, 132 (1973) where quickening is said to usually take place between the $16^{\text {th }}$ and $18^{\text {th }}$ week of pregnancy.

${ }^{216}$ Roe $v$ Wade, 410 US 113, 132 (1973).

217 Ibid 136.

${ }^{218}$ Crimes Act 1900 (NSW) ss 82-4; see also $R v$ Wald [1971] 3 DCR (NSW) 25; Superclinics (1995) 38 NSWLR 47. Both Wald and Superclinics liberally pave the way for social and economic grounds during and after the pregnancy to be determining factors as to whether or not a threat to a mother's psychological health exists, thereby providing greater latitude to justify abortions: see Rankin, 'Contemporary Australian Abortion Law', above n 105, 235 and see generally Douglas, above n 90, 82 .

${ }^{219}$ Crimes Act 1900 (NSW) ss 82-4.

${ }^{220}$ See Rankin, 'Contemporary Australian Abortion Law', above n 105, 235; see generally Talina Drabsch, 'Abortion and the Law in New South Wales' (Briefing Paper No 9, Parliamentary Library, Parliament of New South Wales, 2005) 19-24.
} 
uncertain and 'open to subjective interpretation'. ${ }^{221}$ This is an untenable situation that seriously undermines the NSW criminal law's ${ }^{222}$ ability to protect unborn children's right to life. ${ }^{223}$

The Crimes Act 1900 (NSW) ${ }^{224}$ ostensibly proscribes abortion during any stage of pregnancy. Section 82 provides that a pregnant woman who 'unlawfully administers to herself any drug ... or unlawfully uses any instrument ... with intent ... to procure her miscarriage' is liable to ten years imprisonment. Section 83 provides that any person who 'unlawfully administers to ... any woman, whether with child or not, any drug ... or unlawfully uses any instrument ... with intent ... to procure her miscarriage' is liable to ten years imprisonment. Section 84 provides that any person who 'unlawfully supplies or procures any drug ... or any instrument ... knowing that the same is intended to be unlawfully used with intent to procure the miscarriage of any woman' is liable to five years imprisonment. Whilst these provisions appear to safeguard an unborn child's right to life, the very few cases that have come before NSW courts show that the protection of the right is far from absolute or certain. ${ }^{225}$

The central issue that undermines the NSW criminal law's absolute protection of an unborn child's life is the definition applied by the courts to what constitutes 'unlawful' within the abortion provisions of the Crimes Act 1900 (NSW). ${ }^{226}$ In $R v$ Wald, ${ }^{227}$ the Court suitably followed the decision in $R v$ Davidson; ${ }^{228}$ namely, by stating that the word 'unlawfully' implies that there must be circumstances where abortions are 'lawful', and such circumstances are grounded in the principle of necessity where the mother's life or health is at serious risk. ${ }^{229}$ Importantly, $R v$ Wald $^{230}$ was taken to establish unequivocally that the defence of necessity for an offence under section $83^{231}$

\footnotetext{
${ }^{221}$ Superclinics (1995) 38 NSWLR 47, 63; Rankin, 'Contemporary Australian Abortion Law', above n 105, 237-9.

${ }^{222}$ Crimes Act 1900 (NSW).

${ }^{223}$ Rankin, 'Contemporary Australian Abortion Law', above n 105, 235.

${ }^{224}$ ss $82-4$.

${ }^{225}$ Rankin, 'Contemporary Australian Abortion Law', above n 105, 235, 238-9.

${ }^{226}$ ss $82-4$.

${ }^{227}$ [1971] 3 DCR (NSW) 25.

228 [1969] VR 667.

${ }^{229}$ Ibid 29; see also Part III of this article which discusses in some detail the principle of necessity as it applies to abortion.

${ }^{230}$ [1971] 3 DCR (NSW) 25.

${ }^{231}$ Crimes Act 1900 (NSW).
} 
is available only for the medical profession. ${ }^{232}$ This was to ensure that any such abortion must be 'skilfully performed by qualified medical practitioners with the woman's consent ${ }^{233}$ in order to properly safeguard the woman's health, this being the reason why the abortion was carried out in the first place. ${ }^{234}$ Levine DCJ in that case also expanded - in his discussion of the principle of necessity ${ }^{235}$ - the grounds that may be considered to cause a serious threat to a pregnant woman's mental or physical health. He included non-medical grounds, that is, grounds based on social and economic factors. ${ }^{236}$ Whilst these are ostensibly non-medical factors, they are considered only when they may pose a serious danger to the physical or mental health of the pregnant woman. ${ }^{237}$ However, Levine DCJ limited the period during which the serious danger may materialise to "the currency of the pregnancy, if uninterrupted'. ${ }^{238}$ Such limitation is clearly problematic ${ }^{239}$ and will be discussed shortly. In summary, whilst the NSW criminal law's protection of an unborn child's life is by no means absolute, the exceptions are appropriate and necessary and do not in any way confer upon women a 'right to an abortion'. ${ }^{240}$

Whilst the lack of absolute protection in NSW for unborn children is appropriate when guided by the principle of necessity, the uncertainty surrounding the principle's application in NSW is a real and significant issue. This uncertainty was brought to light in CES v Superclinics (Australia) Pty Ltd ('Superclinics'), ${ }^{241}$ which was a NSW civil case, brought on appeal to the NSW Supreme Court, and which dealt with a medical negligence matter. The case was brought against a number of medical practitioners for failing to diagnose the plaintiff's pregnancy. ${ }^{242}$ However, before dealing with the issue

${ }^{232} R v$ Wald [1971] 3 DCR (NSW) 25, 29; see Rankin, 'Contemporary Australian Abortion Law', above n 105, 234.

${ }^{233}$ Drabsch, above n 224, 20.

${ }^{234}$ Ibid; $R v$ Wald [1971] 3 DCR (NSW) 25, 29.

${ }^{235}$ As espoused by $R v$ Davidson [1969] VR 667.

${ }^{236} R v$ Wald [1971] 3 DCR (NSW) 25, 29; see Rankin, 'Contemporary Australian Abortion Law', above n 105, 234; Drabsch, above n 224, 20.

${ }^{237} R v$ Wald [1971] 3 DCR (NSW) 25, 29.

238 Ibid.

${ }^{239}$ See Superclinics (1995) 38 NSWLR 47, 60.

${ }^{240}$ See Rankin, 'Contemporary Australian Abortion Law', above n 105, 235; see also ibid 82 (Priestly JA).

241 (1995) 38 NSWLR 47.

${ }^{242}$ Ibid; Drabsch, above n 224, 21; Rankin, 'Contemporary Australian Abortion Law', above n $105,237$. 
of uncertainty, it is worth considering what contribution Superclinics ${ }^{243}$ made to the law of abortion in NSW.

The Supreme Court in Superclinics ${ }^{244}$ affirmed the rules espoused in $R v$ Wald $^{245}$ regarding the circumstances that make abortion necessary, ${ }^{246}$ but in the process the Court also made a novel ruling that is worth mentioning. In considering the decision of $R v$ Wald ${ }^{247}$ regarding when abortions are lawful, Kirby ACJ was critical of Levine DCJ's decision to limit to 'the currency of the pregnancy, if uninterrupted', ${ }^{248}$ the period in which any serious danger to the pregnant woman's physical or mental health may materialise. ${ }^{249}$ Kirby ACJ held that a medical practitioner should be permitted to consider the health risks that the continuing pregnancy poses to a pregnant woman beyond the uninterrupted period of the pregnancy alone. ${ }^{250}$ After all, if one has accepted that social and economic circumstances are proper considerations in assessing the health implications of a pregnancy for a pregnant woman, it is illogical to exclude these considerations after the child is born. This is because it is generally then that social and economic factors play their most significant part. ${ }^{251}$ This article accepts that Kirby ACJ's comments are appropriate given the serious risks posed to a woman's psychological health after childbirth ${ }^{252}$ the decision is a far cry from allowing abortion on demand. ${ }^{253}$ So, whilst Superclinics ${ }^{254}$ has allowed post-birth consequences to be taken into account in determining the necessity of an abortion, the actual decision as to whether or not an abortion is necessary to preserve the mother's health is one to be made by medical practitioners alone. ${ }^{255}$ This position

\footnotetext{
243 (1995) 38 NSWLR 47.

244 Ibid.

245 [1971] 3 DCR (NSW) 25.

${ }^{246}$ See Douglas, above n 90, 82.

${ }^{247}$ [1971] 3 DCR (NSW) 25.

${ }^{248}$ Ibid 29.

${ }^{249}$ Superclinics (1995) 38 NSWLR 47, 60 (Kirby ACJ).

${ }^{250}$ Ibid.

251 Ibid.

252 Ibid.

${ }^{253}$ Drabsch, above n 224, 23-4.

25438 NSWLR 47.

${ }^{255}$ Ibid 60, 67; Drabsch, above n 224, 22-4. Note that the term 'medical practitioners' is taken to include those health professionals who are able to assess both physical and mental risks to health — that is, general practitioners, surgeons, psychiatrists, and so forth.
} 
provides a balanced and appropriate safeguard to the health of pregnant women and the lives of unborn children in NSW. ${ }^{256}$

Turning now to the problematic matter of uncertainty, Superclinics ${ }^{257}$ highlights the uncertainty associated with applying the 'necessity principle' to abortion cases. Superclinics ${ }^{258}$ was heard in the first instance by Newman J in the NSW Supreme Court and later, on appeal, in the NSW Court of Appeal. ${ }^{259}$ The substantive law applied in both instances — that is, in the first instance and then on appeal - was identical; both courts considered and applied $R v$ Davidson ${ }^{260}$ and $R v$ Wald. ${ }^{261}$ The issue with the two Superclinics ${ }^{262}$ decisions is that the Court of Appeal decided differently from the court of first instance (the NSW Supreme Court) as to whether or not a 'serious danger' to the woman's mental health existed at the relevant time due to the pregnancy. ${ }^{263} \mathrm{In}$ the first instance the NSW Supreme Court found that an abortion under the circumstances would be unlawful, whereas the NSW Court of Appeal found that under the very same circumstances an abortion would be lawful. ${ }^{264}$ This brings into sharp focus 'the uncertain, and therefore unsatisfactory, state of the law' in NSW with regard to whether or not an abortion is lawful due to a pregnancy posing a 'serious danger' to a mother's health. ${ }^{265}$

More alarmingly, Kirby ACJ of the NSW Court of Appeal acknowledged that what constitutes a 'serious danger' to the health of a pregnant woman thereby justifying an abortion per $R v$ Davidson ${ }^{266}$ and $R v$ Wald $^{267}$ — is 'open to subjective interpretation' ${ }^{268}$ This lack of certainty undermines what would otherwise be quite effective protection under NSW law of the lives of unborn

\footnotetext{
${ }^{256}$ See generally Superclinics (1995) 38 NSWLR 47, 67 (Kirby ACJ); Rankin, 'Contemporary Australian Abortion Law', above n 105, 241.

25738 NSWLR 47.

${ }^{258}$ CES v Superclinics (Unreported, Supreme Court of NSW, Newman J, 18 April 1994); ibid.

${ }^{259}$ Rankin, 'Contemporary Australian Abortion Law', above n 105, 237-8.

${ }^{260}$ [1969] VR 667.

261 [1971] 3 DCR (NSW) 25. Rankin, Contemporary Australian Abortion Law, above n 105, 238.

26238 NSWLR 47; CES v Superclinics (Unreported, Supreme Court of NSW, Newman J, 18 April 1994).

${ }^{263}$ Rankin, ‘Contemporary Australian Abortion Law', above n 105, 238.

${ }^{264}$ Ibid.

${ }^{265}$ Ibid 238-9.

${ }^{266}$ [1969] VR 667.

${ }^{267}$ [1971] 3 DCR (NSW) 25.

${ }^{268}$ Superclinics (1995) 38 NSWLR 47, 73.
} 
children. ${ }^{269}$ It is a significant failing because it sends a message to the NSW justice and prosecuting agencies that the enforcement of abortion crimes is too risky an undertaking to be worthwhile, due to the substantial costs associated with such prosecutions and the considerable uncertainty of the outcome. ${ }^{270}$

Whilst it is lamentable that the criminal law in NSW has a significant chink in its protection of the lives of unborn children, this is something that could be addressed with the necessary political will. All that is required is some legislative provision detailing specific criteria by which a court can judge a 'serious danger' to the health of a mother, and which would make very clear and certain when an abortion is lawful. ${ }^{271}$ When that happens the criminal law in NSW will be able more effectively to discharge one of its purposes: to protect the lives of unborn children and prevent abortion on demand insidiously infiltrating society. ${ }^{272}$

However, it is worth pointing out that the 2006 case of Dr Sood illustrates that NSW has not dropped its guard in the protection of unborn children and its criminal law retains some degree of potency. ${ }^{273}$ Dr Sood was found guilty in the NSW Supreme Court under section 83 of the Crimes Act 1900 (NSW) for failing 'to make the requisite inquiries in order to satisfy herself of the necessity to terminate the pregnancy'. ${ }^{274}$ At the time in question, Dr Sood had 'a history of malpractice and fraud complaints behind her'. ${ }^{275}$ She was ultimately guilty of ${ }^{276}$ not looking into the grounds for the pregnant woman's request for an abortion, ${ }^{277}$ even though the Court found that if Dr Sood had carried out the necessary inquiries, it would have been open for her to form the belief that a termination would be necessary in the circumstances. ${ }^{278} \mathrm{Dr}$ Sood's conviction generated a great deal of public attention, ${ }^{279}$ which served to publicise the need for doctors to diligently inquire into a request for an

\footnotetext{
${ }^{269}$ Rankin, 'Contemporary Australian Abortion Law', above n 105, 241-2.

${ }^{270}$ See generally Superclinics (1995) 38 NSWLR 47, 63, 83; ibid 238-9, 241-2.

271 See generally Rankin, Contemporary Australian Abortion Law, above n 105, 239; Superclinics (1995) 38 NSWLR 47, 63.

272 Drabsch, above n 224, 27.

${ }^{273}$ Douglas, above n 90, 82.

${ }^{274} R v$ Sood [2006] NSWSC 1141, [25].

${ }^{275}$ Douglas, above n 90, 82, see ibid [5].

${ }^{276}$ And thus punishable under the Crimes Act 1900 (NSW) s 83.

${ }^{277} R v$ Sood [2006] NSWSC 1141, [8] - '[Dr] Sood did not carry out a physical examination; nor did she discuss with LT [the pregnant woman] any alternatives to termination, or inquire as to LT's reasons for her determination to proceed [with the abortion]'.

278 Ibid [25].

${ }^{279}$ Ibid [5].
} 
abortion to ensure that such a procedure is carried out only in circumstances of necessity. ${ }^{280}$ The case also served to highlight that there is no abortion on demand in NSW and unborn children are protected under NSW law. ${ }^{281}$

In light of the discussion on NSW, this article contends that the criminal law in that State does promote the right to life of unborn children, but its uncertainty with regard to what constitutes a 'serious danger' undermines its effectiveness. Nevertheless, NSW has demonstrated in its successful prosecution of Dr Sood that its abortion provisions under the Crimes Act ${ }^{282}$ are potent and deserve respect.

The disturbing facts in the Dr Sood case also demonstrate the real need for adequate protection for unborn children. The medication that $\mathrm{Dr}$ Sood provided to the pregnant woman to induce a late-term abortion induced her into labour and she delivered a baby at home in a toilet bowl. ${ }^{283}$ The woman and the baby were taken to hospital where - critical to the tragedy of this whole saga - medical staff observed signs of life in the baby; but because the child's condition was inconsistent with survival, the medical staff made no attempt to resuscitate him. ${ }^{284}$ Poignantly, the Court grappled with the real issue of whether or not the child was born alive. ${ }^{285}$ What is certain is that these disturbing and tragic facts make it clear that abortions must be properly controlled through use of the principle of necessity. Effective criminal laws are needed to ensure that abortions not driven by necessity do not arise, or, when they do arise, they are properly dealt with by way of criminal prosecution.

\section{Queensland}

The law with regard to abortion in Queensland is in many respects similar to that of NSW. ${ }^{286}$ Therefore, this article will deal only with the salient aspects of Queensland's abortion law.

\footnotetext{
${ }^{280}$ Douglas, above n 90, 82.

${ }^{281}$ Rankin, 'Contemporary Australian Abortion Law', above n 105, 235; $R v$ Sood [2006] NSWSC 1141; ibid.

2821900 (NSW).

${ }^{283} R v$ Sood [2006] NSWSC 1141, [9]-[11].

${ }^{284}$ Ibid [10].

${ }^{285}$ Ibid [11].

${ }^{286}$ Rankin, 'Contemporary Australian Abortion Law', above n 105, 230-1; Dean, above n 3 , 157; Victorian Law Reform Commission, above n 102, 20.
} 
The abortion provisions in Queensland are contained in the Criminal Code Act 1899 (Qld) and they proscribe abortions at any stage during the pregnancy. ${ }^{287}$ Section $224^{288}$ provides that '[a]ny person who, with intent to procure the miscarriage of a woman,... unlawfully administers to her ... any poison ... or uses any force of any kind' is liable to 14 years imprisonment. ${ }^{289}$ Section 225 provides that '[a]ny woman who, with intent to procure her own miscarriage,... unlawfully administers to herself any poison... or uses any force of any kind ... or permits such thing or means to be administered or used to her' is liable to seven years imprisonment. ${ }^{290}$ Section 226 provides that '[a]ny person who unlawfully supplies to or procures for any person anything whatsoever, knowing that it is intended to be unlawfully used to procure the miscarriage of a woman' is liable to three years imprisonment. ${ }^{291}$ In many respects, these provisions are similar to those in NSW and their interpretation is therefore influenced to a large extent by the same case law. ${ }^{292}$

Whilst the aforementioned provisions create offences relating to unlawful abortions, section $282^{293}$ provides a statutory defence to doctors who carry out abortions via surgical operations or medical treatment, so long as the operation or treatment was conducted 'in good faith and with reasonable care and skill ... to preserve the mother's life ... [where such] ... operation ... or treatment [was] reasonable, having regard to ... all the circumstances of the case'. ${ }^{294}$ Therefore, like NSW, Queensland punishes with criminal sanctions those who perform abortions; but, unlike NSW, Queensland provides a statutory defence for medical practitioners. However, this defence provision appears to be intended to expressly protect doctors in circumstances where a patient is unable to provide consent due to unconsciousness, and so forth. ${ }^{295}$ Therefore, the case law determining circumstances in which abortions are deemed lawful and unlawful still applies in Queensland. ${ }^{296}$

\footnotetext{
${ }^{287}$ Criminal Code Act 1899 (Qld) ss 224-6.

${ }^{288}$ Criminal Code Act 1899 (Qld).

${ }^{289}$ Ibid s 224.

${ }^{290}$ Ibid s 225.

${ }^{291}$ Ibid s 226.

${ }^{292}$ Rankin, 'Contemporary Australian Abortion Law', above n 105, 230-1; Douglas, above n 90, 77-8; Nicolee Dixon, 'Abortion Law Reform: An Overview of Current Issues' (Research Brief No 9, Parliamentary Library, Parliament of Queensland, 2003) 13-5.

${ }^{293}$ Criminal Code Act 1899 (Qld).

${ }^{294}$ Criminal Code Act 1899 (Qld) s 282.

${ }^{295}$ Dixon, above n 297, 13.

${ }^{296} K v T$ [1983] 1 Qd R 396, 398; R v Bayliss and Cullen (1986) 9 Qld Lawyer Reps 8, 30, 45; Douglas, above n 90, 77-8; see ibid 13-5.
} 
The significant cases on abortion in Queensland centre on the legal question of what constitutes a 'lawful abortion'. ${ }^{297}$ In $K v T,{ }^{298}$ the Court held that the principle of necessity as outlined in $R v$ Davidson $^{299}$ represents the law in Queensland with regard to when an abortion is lawful. ${ }^{300}$ This position was endorsed later in $R v$ Bayliss and Cullen $^{301}$ in which McGuire $\mathrm{J}$ stressed, whilst supporting the $R v$ Davidson ${ }^{302}$ defence of necessity, that the defence is not available to excuse the termination of 'every inconvenient conception' and that only 'in exceptional cases' will abortions be deemed lawful. ${ }^{303}$ The point on which the law in Queensland possibly differs from that of NSW is the question of whether or not social and economic factors could be considered in assessing whether a serious danger to a pregnant woman's health exists. ${ }^{304}$ It could be stated truly that $R v$ Davidson ${ }^{305}$ certainly represents the law in Queensland and $R v$ Wald $^{306}$ probably represents the law in Queensland. ${ }^{307}$ The effect of these decisions is that the availability of abortions in Queensland is more restricted than in NSW due in part to the uncertainty around whether or not $R v$ Wald $^{308}$ applies. ${ }^{309}$

Another important case on what constitutes a 'lawful abortion' is Veivers $v$ Connolly, ${ }^{310}$ which was a civil case. The critical aspect of this case, for the purpose of this article, is that the court came to a similar conclusion to the court in Superclinics $^{311}$ - the conclusion that, in determining whether an abortion is lawful, any relevant danger to the mental health of the pregnant woman need not arise during the pregnancy, but could arise after the child's

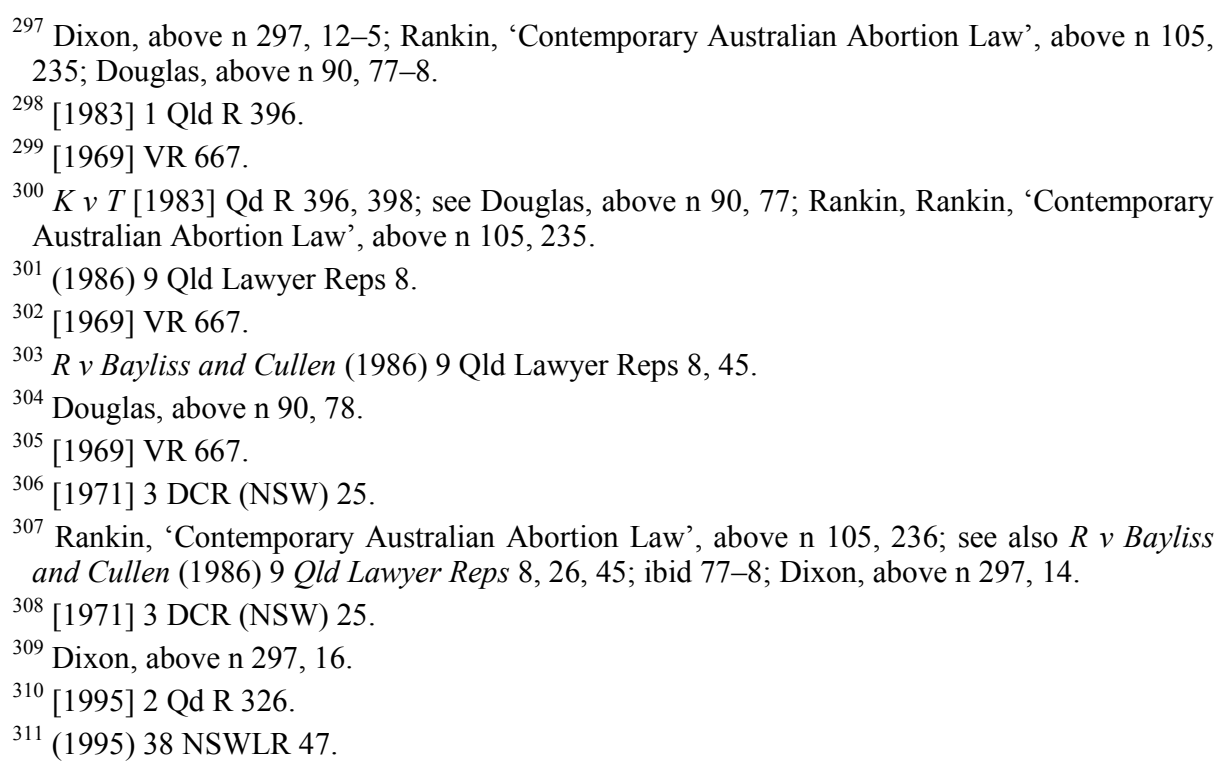


birth. ${ }^{312}$ However, only Kirby ACJ in Superclinics ${ }^{313}$ determined that the $R v$ Wald $^{314}$ test $^{315}$ could be extended to the consideration of health effects on mothers after the birth of their children. ${ }^{316}$ The remaining uncertainty around whether or not social or economic factors play a part in determining the lawfulness of an abortion therefore continues to hamper access to abortion in Queensland. ${ }^{317}$

Whilst the more restricted availability of abortion in Queensland ${ }^{318}$ is welcomed in the interests of safeguarding the lives of unborn children, there needs to be a properly balanced, certain and effective safeguard to ensure that the health of pregnant women is not unduly jeopardised simply because medical practitioners fear possible prosecution under the Queensland criminal jurisdiction. ${ }^{319}$ This article contends that, to fulfil this need, social and economic factors should certainly be taken into account when the impact that a pregnancy may have on the physical and mental health of a pregnant woman is being assessed. The current uncertainty around this area of the law in Queensland improperly causes the gate-keepers of abortion in Queensland the medical profession - to hesitate and even deny an abortion in circumstances where social and economic factors bear heavily on the health of a pregnant woman. ${ }^{320}$ Therefore, legislation should be passed to make certain the factors that could be considered in assessing the 'serious danger' to the health of pregnant women. Such legislation would instil confidence in medical practitioners in the decisions they make and safeguard them from criminal prosecution. ${ }^{321}$

Notwithstanding the uncertainty around Queensland's acceptance of $R v$ Wald, ${ }^{322}$ the situation in Queensland is that in general terms its criminal law

\footnotetext{
${ }^{312}$ Veivers v Connolly [1995] 2 Qd R 326, 329.

313 (1995) 38 NSWLR 47.

314 [1971] 3 DCR (NSW) 25.

${ }^{315}$ This test refers to the 'necessity test' for determining if an abortion is lawful, and this test includes the consideration of social and economic factors to determine if there is a serious danger to the health of the pregnant woman: ibid 29.

316 Superclinics (1995) 38 NSWLR 47, 59-60.

${ }^{317}$ Dixon, above n 297, 16; see also Rankin, 'Contemporary Australian Abortion Law', above n $105,240$.

${ }^{318}$ Dixon, above n 297, 17.

${ }^{319}$ Douglas, above n 90, 86; see also Criminal Code Act 1899 (Qld) s 224.

${ }^{320}$ See generally Douglas, above n 90, 86 .

${ }^{321}$ See generally ibid; note that the term 'medical practitioners' is used here in its widest possible sense to include health professionals qualified to treat the physical and mental health of their patients.

322 [1971] 3 DCR (NSW) 25; see Douglas, above n 90, 78; Dixon, above n 297, 14.
} 
serves to promote the right to life of unborn children. The law in Queensland remains a 'guardian of the silent innocence of the unborn' and uses its power to ensure that 'abortion on whim or caprice does not insidiously filter into ... society'. ${ }^{323}$ There is no abortion on demand in Queensland, ${ }^{324}$ and this position is reinforced by the recent prosecution of a Queensland couple for procuring their own abortion. ${ }^{325}$

\section{Issues with Disparate Approaches by Jurisdictions to Criminal Statutes on Abortion}

This article illustrates that one Australian jurisdiction can be poles apart from another in the position it takes on abortion. ${ }^{326}$ Whilst there is no doubt that the jurisdictions which have a liberal attitude towards abortion fail to promote the right to life of unborn children, the issue that needs to be considered is how these liberal jurisdictions undermine the conservative jurisdictions' efforts to protect the lives of unborn children through their respective criminal laws.

The practical effect of the lack of uniformity in abortion laws across Australia is that one jurisdiction's effort to protect the lives of unborn children is easily circumvented by pregnant women travelling to a liberal jurisdiction in search of an abortion. ${ }^{327}$ For example, residents of NSW and Queensland have ample time to travel to Victoria or the ACT for an abortion. This is because 99.3 percent of abortions throughout Australia take place before 20 weeks gestation, ${ }^{328}$ and such abortions would be legal and a matter of a pregnant woman's discretion in Victoria and the ACT. ${ }^{329}$ Unlike criminal offences such as murder, robbery, theft, deception, serious assault and rape, an abortion is

\footnotetext{
${ }^{323} R v$ Bayliss and Cullen (1986) 9 Qld Lawyer Reps 8, 45.

324 Ibid.

${ }^{325} R v$ Leach and Brennan (Unreported, Qld District Court, Everson J, 2010), although in this case the couple was found not guilty under the Criminal Code Act 1899 (Qld) ss 225-6 on the basis that the RU486 abortion pill was deemed to be not noxious to the mother; see also Wendy Carlisle, Crown Kicks Own Goal in Qld Abortion Trial (15 October 2010) ABC The Drum $<$ http://www.abc.net.au/news/stories/2010/10/15/3038945.htm>.

${ }^{326}$ Bronitt and McSherry, above n 64, 491.

${ }^{327}$ Kennedy, above n 103, 36-7.

${ }^{328}$ Victorian Law Reform Commission, above n 102, 36.

${ }^{329}$ See Abortion Law Reform Act 2008 (Vic) ss 1, 4-5, which repeals the crime of abortion and permits abortions to be carried out up to 24 weeks into the pregnancy (and beyond that period with the approval of two doctors); Crimes (Abolition of Offence of Abortion) Act 2002 (ACT) ss 3, 44, which repeal abortion crimes; Crimes Act 1900 (ACT) s 42, which creates an offence to commit 'child destruction', and this provision is interpreted as applying only to a viable foetus, which is one aged 22 weeks or more; Rankin, 'Recent Developments in Australian Abortion Law', above n 158, 331.
} 
something that can be carefully considered, planned and, most critically, transferred to an accommodating liberal jurisdiction. It is extremely rare for a woman not to have an early notification of her pregnancy; in fact, whilst Superclinics ${ }^{330}$ illustrates a failure on the part of doctors to diagnose the plaintiff's pregnancy until she was 19.5 weeks pregnant, she was very suspicious quite early on that she was expecting a child. ${ }^{331}$ All these factors conspire to allow individuals seeking abortions to 'forum shop' across jurisdictions to circumvent the practical effect of existing criminal laws proscribing abortion. ${ }^{332}$

The availability of abortions at the discretion of pregnant women in liberal jurisdictions also serves to undermine the moral authority of the law in conservative jurisdictions. Of all the criminal prosecutions discussed, Dr Sood's matter stands out as the only one returning a guilty verdict. ${ }^{333}$ But, even after acknowledging the 'seriousness of the offences committed by ... [Dr] Sood' ${ }^{334}$ the Court nevertheless decided to impose a non-custodial sentence. ${ }^{335}$ To say this is not to criticise judicial decisions or prosecution outcomes; it is merely to highlight the fact that a prosecution may not result in a sentence with any meaningful deterrence value.

Even when a prosecution is brought, the public outcry against the prosecution is almost deafening —as was the case in the recent prosecution against Leach and Brennan in Queensland. ${ }^{336}$ The arguments commonly used to criticise the legal position in the 'pro-life' jurisdictions generally involve highlighting the liberal position of the law in 'pro-choice' jurisdictions. ${ }^{337}$ It appears,

\footnotetext{
330 (1995) 38 NSWLR 47.

${ }^{331}$ Ibid; Drabsch, above n 224, 21-2.

${ }^{332}$ Kennedy, above n 103, 36-7.

${ }^{333} R v$ Davidson [1969] VR 667; $R v$ Wald [1971] 3 DCR (NSW) 25; $R v$ Bayliss and Cullen (1986) 9 Qld Lawyer Reps 8; $R v$ Leach and Brennan (Unreported, Qld District Court, Everson J, 2010); $R v$ Sood [2006] NSWSC 1141.

${ }^{334} R v$ Sood [2006] NSWSC 1141, [69].

${ }^{335}$ Ibid [71] where the court ordered Dr Sood 'to enter into a good behaviour bond for a period of two years'. The reason for this was primarily because of Dr Sood's poor health: at [54][57], [69].

336 For example, Rick Feneley, 'Law Unto Itself: Abortion Crime Still Lurks in Legal Shadows', The Sydney Morning Herald (online), 16 October $2010<\mathrm{http}: / / w w w . s m h . c o m . a u /$ lifestyle/lifematters/law-unto-itself-abortion-crime-still-lurks-in-legal-shadows-20101015-16n n4.html>; 'Calls for Law Reform After Abortion Case', The Daily Telegraph (online), 14 October $2010<\mathrm{http}$ //www.dailytelegraph.com.au/news/breaking-news/calls-for-law-reformafter-abortion-case/story-e6freuz0-1225938762760>.

${ }^{337}$ Douglas, above n 90, 74, 84-6; Rankin, 'Recent Developments in Australian Abortion Law', above n 158, 317, 327; Feneley, above n 341.
} 
therefore, that the moral underpinning of abortion laws in jurisdictions such as NSW and Queensland is seriously undermined by the lack of uniformity in Australia's abortion laws. ${ }^{338}$

This article contends that there needs to be uniformity in Australia's approach to abortion in order for the criminal law in conservative jurisdictions to effectively promote the right to life of unborn children. Forum shopping circumvents the laws controlling and restricting abortion and renders them ineffective, and 'pro-choice' jurisdictions undermine the moral authority of such laws.

On this second point, a quote from Horace Rumpole in the fictitious work of John Mortimer serves in part to illustrate the matter: 'You're not concerned with the law, Members of the Jury ... you are concerned with justice! ${ }^{339}$ The temptation for juries to step outside their strict legal role of tribunals of fact is perhaps evident when we consider whether or not juries in abortion cases in pro-life jurisdictions are going to convict a person, and thereby possibly send that person to gaol, for doing what is allowed elsewhere. It is a valid question - one this article does not seek to answer, only to consider. What is certain is that there needs to be a concerted effort on the part of all Australian governments to establish a uniform approach promoting the right to life of unborn children - anything less will undoubtedly continue to sabotage the current efforts of pro-life jurisdictions. ${ }^{340}$

\section{Public Policy on the Right to Life for Unborn Children}

In establishing the need for a uniform approach to abortion laws across Australia to protect the lives of unborn children, this article will now briefly put forth recommendations of public policy for consideration.

Naturally, to achieve uniformity in abortion laws across Australia, it needs to be established what the Australian position is. Currently, there appears to be an avalanche of support for decriminalising abortion and making abortion a

\footnotetext{
${ }^{338}$ See generally Rankin, 'Contemporary Australian Abortion Law', above n 105, 235; Dixon, above $n$ 297, 16. Both articles highlight the relatively easy access to abortion in the pro-life States of NSW and Queensland.

339 John Mortimer, Rumpole à la Carte in The Third Rumpole Omnibus (Penguin Books, 1998) 265.

${ }^{340}$ Drabsch, above n 224, 50.
} 
matter of personal choice for women. ${ }^{341}$ However, this article contends that the state must exercise its 'responsibility as guardian of the silent innocence of the unborn' and use its authority to prevent the occurrence of abortions on demand. ${ }^{342}$ The argument that women should be free to choose abortion is critically flawed when one considers that invoking this freedom results in the destruction of innocent life - at least the potential life of an unborn child. ${ }^{343}$ With such a significant interest being put at risk through the legalisation of abortion on demand, a safeguard is necessary to ensure that abortions take place only as a matter of necessity. ${ }^{344}$ It is the contention of this article that this should be the Australian legal position.

This article contends that the existing criminal law safeguards in pro-life jurisdictions such as NSW and Queensland could be improved to ensure legal certainty for all relevant stakeholders, namely medical staff and pregnant women. Legislation should spell out in the clearest terms possible the circumstances that necessitate an abortion and thus make it lawful. The issue of what clearly constitutes 'serious danger' should be addressed to ensure that it is not 'open to subjective interpretation' by the courts. ${ }^{345}$ The question of whether or not social and economic factors attributable to the pregnancy can be considered in determining whether any serious danger exists to the health of the mother should be put to rest; these factors should be considered, as they do on occasion play seriously on the mind of pregnant women, seriously undermining their health. ${ }^{346}$ With a uniform pro-life legal policy on abortion coupled with these improvements, Australian law can serve to protect the weakest in the community — unborn children ${ }^{347}$ — and safeguard their right to life, whilst giving due respect to the health concerns of pregnant women. ${ }^{348}$

It should therefore be a matter of policy that abortions in Australia only take place as a matter of necessity.

\footnotetext{
341 Victorian Law Reform Commission, above n 102, 58-68; Douglas, above n 90, 74, 86; Rankin, 'Recent Developments in Australian Abortion Law', above n 158, 334-5.

${ }^{342} R v$ Bayliss and Cullen (1986) 9 Qld Lawyer Reps 8, 45; see also Sacred Congregation for the Doctrine of Faith, Declaration on Procured Abortion (18 November 1974) Vatican: The Holy See, [21] <http://www.vatican.va/roman_curia/congregations/cfaith/documents/rc_con_ cfaith_doc_19741118_declaration-abortion_en.html $>$.

${ }^{343}$ Bronitt and McSherry, above n 64, 492; Sacred Congregation for the Doctrine of Faith, above n 347, [20]; see generally Roe $v$ Wade, 410 US 113, 150, 154, 156, 159, 162 (1973).

${ }^{344}$ See generally $R v$ Davidson [1969] VR 667; $R v$ Wald [1971] 3 DCR (NSW) 25; $R v$ Bayliss and Cullen (1986) 9 Qld Lawyer Reps 8.

${ }^{345}$ Superclinics (1995) 38 NSWLR 47, 63.

${ }^{346} R v$ Wald [1971] 3 DCR (NSW) 25, 29; Douglas, above n 90, 78.

${ }^{347}$ See generally Sacred Congregation for the Doctrine of Faith, above n 347, [21].

${ }^{348}$ See generally $R v$ Davidson [1969] VR 667, 672.
} 


\section{CONCLUSION}

It is the contention of this article that human life has an intrinsic value from the moment of its conception based on its potential use to the community. ${ }^{349}$ This value to the community demands protection from the state in much the same way that any important public utility demands protection by the state. Whilst the 'born alive' principle in Australia is used to deny rights to an unborn child, it is merely a principle of convenient simplicity and legal fiction $^{350}$ and is shown to be deficient when held up against the laws of other nations. ${ }^{351}$ These laws properly recognise that unborn children have a right to life and that such a right requires state protection.

Whilst this article calls for the protection of unborn children, there is a need to balance this aim against the legitimate health interests of pregnant women. Abortions should be permitted only in circumstances where the abortion is necessary to preserve the pregnant woman from any serious danger to her physical or mental health. This should be a matter for medical practitioners ${ }^{352}$ to determine, and social and economic factors - along with medical factors - should be taken into account when forming such determinations. What is certain, however, is that the potential value of human life should never be so underestimated that abortions on demand are permitted for frivolous reasons.

This article has examined the law in two pro-choice jurisdictions - Victoria and the ACT - which have decriminalised abortion, making it possible for women to have abortions on demand. This position has been contrasted with that in the staunch pro-life jurisdictions, NSW and Queensland, where abortion remains a serious crime when undertaken for reasons other than necessity on maternal health grounds. Whilst the criminal law in NSW and Queensland has certain imperfections, which have been discussed in this article, the law in these jurisdictions nevertheless serves to promote the right to life of unborn children.

Moreover, it is abundantly clear that without a uniform approach to the law of abortion, those jurisdictions with liberal abortion laws undermine the efforts of conservative jurisdictions to safeguard the lives of unborn children through the criminal law. Those women seeking an abortion can 'forum shop',

\footnotetext{
${ }^{349}$ Dworkin, above n 4, 2, 11, 13; Lazarev, above n 9, IV; Roe v Wade, 410 US 113, 150, 154, $156,159,162$ (1973).

${ }^{350}$ Stewart and Stuhmcke, above n 32, 272.

${ }^{351}$ Such as Ireland and the Philippines.

352 That is, health professionals qualified to treat the physical and mental issues of their patients.
} 
travelling to jurisdictions that permit abortions on demand. The existence of pro-choice laws in liberal jurisdictions also undermines the moral authority of the legal stance of conservative jurisdictions. All in all, this lack of a uniform approach in Australia to the protection of the right to life of unborn children sabotages existing safeguards put in place by pro-life jurisdictions.

This article contends that there needs to be a uniform approach to the question of abortion in Australia. The criminal law needs to be improved to make clear to medical staff, pregnant women and members of the community that abortion is allowed only in circumstances of necessity and to provide certainty as to what constitutes such circumstances. For a few jurisdictions to adopt this approach on their own will be largely ineffective, leaving the most vulnerable, silent and defenceless in Australian society without legal protection. This should not be allowed to happen. 